\title{
Fenomena Segitiga Bermuda Menurut Padangan Filsafat dan Sains
}

\author{
Ma'ruf \\ Program Doktor Departemen Pendidikan IPA, Sekolah Pascasarjana \\ Universitas Pendidikan Indonesia \\ Bandung, Indonesia \\ e-mail: maruf@upi.edu
}

\begin{abstract}
Segitiga bermuda dalam bahasa inggris biasa disebut termuda triangle, kadang - kadang disebut juga Segitiga Setan yaitu sebuah wilayah lautan di Samudra Atlantik seluas 1,5 juta mil² atau 4 juta $\mathrm{km}^{2}$ yang membentuk garis Segitiga bermuda, wilayah teritorial Britania Raya sebagai titik di sebelah Utara, Puerto Riko, teritorial Amerika Serikat sebagai titik di sebelah Selatan, dan Miami, negara bagian Florida, Amerika Serikat sebagai titik di sebelah barat. Segitiga bermuda sangat misterius. Sering ada isu paranormal di daerah tersebut yang menyatakan alasan dari peristiwa hilangnya kapal yang melintas, ada pula yang mengatakan bahwa sudah menjadi gejala alam bahwa tidak boleh melintasi daerah tersebut, bahkan ada pula yang mengatakan bahwa itu semua akibat ulah mahluk luar angkasa.
\end{abstract}

Kata Kunci : Fenomena Segitiga Bermuda, filsafat, sains

\section{Pendahuluan}

Kawasan berbentuk segitiga di samudra Atlantis yang dibatasi oleh Bermuda, Puerto Rico dan Fort Lauderdale-Florida ini, sebelum tahun 1964 mempunyai julukan-julukan yang terkenal, tetapi karena adanya laporan-laporan aneh yang terjadi di situ atau di dekatnya yang tercatat selama berabad-abad. Pada kenyataannya, banyak yang mengatakan bahwa Christopher Columbus adalah salah satu saksi keanehan Segitiga Bermuda ini. Ketika kapalnya, Nina, Pinta dan Santa Maria berlayar melintasi kawasan itu pada tahun 1492, dilaporkan bahwa kompas Columbus bergerak kacau dan bahwa mereka melihat cahaya aneh di angkasa, dalam catatan yang dibuat Columbus, ketidak-tepatan kompasnya dikiranya tidak lebih dari ketidak cocokan antara arah utara yang sebenarnya dan arah utara magnetik. Sedangkan mengenai cahaya di langit, Columbus menulis, dia melihat nyala api yang besar sekali, yang akhirnya jatuh ke laut, kemungkinan sebuah meteor. Sekali lagi dia melihat cahaya di angkasa pada tanggal 11 Oktober. Ini adalah sehari sebelum pendaratannya yang sangat terkenal itu. Cahaya itu berkelebat di dekat Cakrawala, di mana benua yang hilang itu berada.

Kejadian bersejarah lain yang sampai sekarang masih ada tentang segitiga Bermuda adalah penemuan kembali Mary Celeste, kapal layan ini ditemukan telah ditinggalkan di tengah laut pada tahun 1892, kira-kira 400 mil diluar jalurnya dari New York menuju ke Genoa, tak ada tanda-tanda keberadaan 10 orang awaknya atau apa yang terjadi pada mereka, karena sekocinya juga hilang, kemungkinan besar mereka meninggalkan Mary Celeste karena amukan badai yang mereka perkirakan tidak akan dapat ditahan oleh kapal itu, tetapi apa yang semakin membuat segitiga Bermuda ini bertambah misterius adalah karena kapal itu tidak berada di dekat segitiga Bermuda, tetapi ditemukan di lepas pantai Portugal.

Legenda segitiga Bermuda ini sebenarnya dimulai pada tanggal 5 Desember 1945, dengan hilangnya penerbangan 19 yang sangat terkenal itu, lima pesawat pembom hilang dalam misi latihan rutin, demikian juga tim penyelamat yang mencari mereka yang terdiri dari enam pesawat terbang dengan 27 awak, hilang tanpa jejak, tidak ditemukan serpihan penerbangan 19 itu.

Ada kurang lebih 200 kecelakaan besar dan aneh yang menambah kemisteriusan kawasan itu, seorang penulis bernama V. Gaddis pada tahun 1964 menjuluki kawasan itu dengan Segitiga Bermuda, dalam sebuah artikel di majalah fiksi, Argosy. Masyarakat begitu 
tertarik pada phenomena ini dan lebih dipacu lagi oleh buku best seller tulisan Charles Berlitz yang juga berjudul Segitiga Bermuda. Banyak orang masih penasaran dan terus mencari petunjuk-petunjuk baru, untuk membuktikan adanya Atlantis dan Segitiga bermuda ini. Ataukah ini semua hanyalah isapan jempol atau kisah fiksi semata?

Segitiga bermuda yang juga biasa disebut segitiga setan terletak di wilayah lautan Samudera Atlantik seluas 1,5 juta $\mathrm{mil}^{2}$ atau 4 juta $\mathrm{km}^{2}$ yang membentuk garis segita antara wilayah teritorial britania raya sbg titik di sebelah utara, puerto rico teritorial amerika serikat titik di sebelah selatan dan miami negara bagian florida amerika serikat sbg titik disebelah barat.

Asal kata Segitiga Bermuda, seperti yang kita sebut hari ini, diciptakan oleh penulis Vincent Gaddis pada tahun 1964 ketika ia menulis sebuah cerita sampul untuk majalah Argosy tentang menghilangnya Penerbangan 19 secara misterius. Juga dikenal sebagai 'Segitiga Setan' atau 'Pulau Setan', Menurut banyak ilmuwan hari ini, bagaimanapun batas-batas misteri itu didefinisikan antara fantasi dan fiksi. Berdasarkan permasalahan tersebut, maka lahirlah pandangan filsafat dan sains terhadap fenomena segitiga bermuda tersebut.

\section{Berbagai fenomena segitiga bermuda berdasarkan mitos monster laut}

Berbagai literatur dari masa lalu menyebutkan jika misteri segitiga bermuda memiliki hubungan dengan legenda mengerikan soal makhluk purba misterius. Kawasan misteri itu memang menaungi lautan Sargasso yang sudah lama dikenal sebagai lokasi yang didiami makhluk-makhluk misteri. Sargasso mempunyai panjang $3.650 \mathrm{~km}$ dan lebar $1.825 \mathrm{~km}$ yang kabarnya menjadi habitat dari hewan raksasa seperti naga laut. Pada abad ke-16, Olaus Magnus pernah membuat sebuah peta lautan bernama Carta Marina yang menjelaskan ada seekor naga merah sedang menyerang kapal. Titik di mana naga itu berada adalah laut Sargasso di Bermuda. Jadi, apakah memang segitiga bermuda merupakan sarang dari naga laut raksasa yang doyan memakan kapal atau pesawat terbang.

\section{Lidah samudra}

Hal yang membuat segitiga bermuda menjadi begitu mengerikan adalah bagaimana banyak sekali kisah kapal laut dan pesawat terbang yang melintas di atasnya mendadak hilang. Salah satu teori yang muncul dan diduga sebagai penyebab kasus hilang itu adalah bahwa segitiga bermuda merupakan Lidah Samudera. Banyak peneliti yang percaya bahwa di bawah lautan Bermuda terdapat palung raksasa yang tampak menyerupai jurang besar sehingga membahayakan apa saja yang melintas di atasnya (terutama kapal laut) karena rawan tenggelam. Meskipun begitu teori ini masih dipertanyakan karena sampai saat ini belum ada yang bersedia menyelam ke bawah segitiga bermuda dan kembali dengan selamat.

\section{Lautan iblis}

Salah satu yang paling dekat dengan teori segitiga bermuda adalah lautan iblis. segitiga bermuda kerap dijuluki sebagai rumah iblis karena sudah tak terhitung korban jiwa yang hilang misterius di kawasan itu. Banyak yang menyebutkan jika korban jiwa yang gugur di sana adalah menjadi tumbal bagi sebuah kekuatan misterius jahat yang tak diketahui. Bahkan beberapa teori dunia mistis menyebutkan kalau segitiga bermuda merupakan sarang dari dajjal, sosok yang dianggap akan muncul di akhir zaman nanti. dajjal sendiri kerap disebut sebagai sang raja iblis yang kini sedang diam menanti di bawah gelapnya lautan bermuda sebelum akhirnya nanti muncul.

\section{Gas metana di laut}

Setelah banyak teori mistis dan mitos mengenai segitiga bermuda, ada salah satu yang dianggap cukup masuk akal. Teori itu adalah segitiga bermuda merupakan penghasil gas metana terbesar di dunia. Jika Anda tidak tahu, metana adalah sebuah senyawa yang begitu kuat dan tentunya berbahaya. Bahkan bahaya metana dianggap beberapa ilmuwan lebih berbahaya daripada karbondioksida (CO2). Penelitian ini dianggap masuk akal karena laut merupakan penghasil metana paling besar di alam selain di lapisan es atau tanah. Bahkan pada tahun 1981, sebuah uji coba seolah membenarkan jika segitiga bermuda memiliki kandungan metana dalam jumlah besar. Yang bisa menjadi biang keladi mengapa banyak pesawat dan kapal laut hilang di sana.

\section{Pintu gerbang alien}

Selain segitiga bermuda, salah satu hal lain yang juga menjadi misterius di dunia ini adalah misteri mengenai penampakan UFO dan ras alien, makhluk yang dipercaya tinggal di planet lain di jagat raya ini. Banyak teori yang menyebutkan jika segitiga bermuda merupakan sebuah gerbang lorong waktu dan pergi ke dimensi lain. Beberapa penelitian menyebutkan jika ada banyak anomali yang terjadi di bermuda dan memberikan efek ke atmosfir Bumi. Memiliki daya tarik magnetik yang tinggi, hal itu membuat banyak kapal laut dan pesawat terbang tertarik 
masuk ke segitiga bermuda. Tak heran kalau akhirnya muncul dugaan jika Bermuda menjadi pintu gerbang ke luar angkasa dan jalan keluar-masuk UFO.

\section{Pusaran angin raksasa}

Banyak orang meyakini jika di lautan segitiga bermuda ada sebuah angin berkekuatan besar yang berhembus mirip tornado. Kekuatan angin itu bahkan diduga mampu menghisap pesawat maupun kapal laut yang melintas di sana sehingga mampu menariknya masuk ke dalam lautan bermuda.

\section{Metode}

Adapun metode penelitian yang digunakan adalah metode studi literasi dengan menggunakan pendekatan kajian kepustakaan. Sumber data yang digunakan adalah referensi berupa jurnal filsafat, buku filsafat, dan berbagai artikel lainnya yang membahas tentang fenomena segitiga Bermuda. Hasil kajian kepustakaan ini dianalisis dan dielaborasi berdasarkan padangan filsafat dan sains.

\section{Hasil dan Pembahasan}

Pandangan filsafat pada fenomena segitiga bermuda menurut pendekatan eksplanasi analogi. Menurut beberapa peneliti,mungkin dikawasan ini terdapat sebuah gangguan atmosfir di udara berupa lubang di langit. Di lubang itulah pesawat terbang masuk tanpa sanggup untuk keluar lagi. Dari misteri "Lubang di Langit" ini membentuk sebuah teori tentang adanya semacam perhubungan antara dunia dengan dimensi lain. Lubang di langit ini dianalogikan seperti lubang hitam yang terbentuk di ruang angkasa yang memiliki kekuatan untuk menghisap/menelan benda-benda yang berada didekatnya. Selain itu, banyak orang meyakini jika di lautan segitiga bermuda ada sebuah angin berkekuatan besar yang berhembus dan dianalogikan seperti angin tornado. Kekuatan angin itu bahkan diduga mampu menghisap pesawat maupun kapal laut yang melintas di sana sehingga mampu menariknya masuk ke dalam lautan bermuda.

\section{Pandangan sains pada fenomena segitiga bermuda}

Perusahaan asuransi laut Lloyd's of London menyatakan bahwa segitiga bermuda bukanlah lautan yang berbahaya dan sama seperti lautan biasa di seluruh dunia, asalkan tidak membawa angkutan melebihi ketentuan ketika melalui wilayah tersebut. Penjaga pantai mengkonfirmasi keputusan tersebut. Penjelasan tersebut dianggap masuk akal, ditambah dengan sejumlah pengamatan dan penyelidikan kasus. Menurut beberapa peneliti,mungkin dikawasan ini terdapat sebuah gangguan atmosfir di udara berupa lubang di langit. Di lubang itulah pesawat terbang masuk tanpa sanggup untuk keluar lagi. Dari misteri "Lubang di Langit" ini membentuk sebuah teori tentang adanya semacam perhubungan antara dunia dengan dimensi lain. Lubang di langit itu dianggap semacam alat transportasi seperti tampak di film Star Trek. Ataukah bentuk Lubang di Langit itu UFO? Orang sering menghubungkan hilangnya pesawat kita dengan munculnya UFO.

Konon di dasar laut segitiga bermuda terdapat semacam lubang/gua dasar laut,dulu gua ini memang sungguh ada, tetapi setelah jaman es berlalu, gua ini tertutup.Arus didalamnya sangat kuat dan sering membuat pusaran yang berdaya hisap. Banyak kapal-kapal kecil atau manusia yang terhisap ke dalam blue hole itu tanpa daya,dan anehnya kapal-kapal kecil yang terhisap itu akan muncul kembali kepermukaan laut selang beberapa lama. Tapi yang menimbulkan pertanyaan ialah: Mungkinkah Blue Hole ini sanggup menelan kapal raksasa ke dasar lautan tersebut. Beberapa laporan mengatakan bahwa sebanyak 1.000 jiwa telah hilang dalam 500 tahun terakhir dan bahwa lebih dari 50 kapal dan 20 pesawat telah hilang dalam 1 abad terakhir. Angkatan Laut AS dan Coast Guard mengatakan ada bukti kegiatan yang tidak biasa di daerah tersebut. Lalu apakah ada hubungannya dengan perjalanan waktu? Dugaan ini masih luas beredar di kalangan masyarakat dunia. Namun, ada yang berpikir Segitiga Bermuda memiliki 'lubang biru' dianggap sisa-sisa lubang cacing dimana alien lintas dimensi melakukan perjalanan ke Bumi.

Setelah banyak teori mistis dan mitos mengenai segitiga bermuda, ada salah satu yang dianggap cukup masuk akal. Teori itu adalah segitiga bermuda merupakan penghasil gas metana terbesar di dunia. Jika Anda tidak tahu, metana adalah sebuah senyawa yang begitu kuat dan tentunya berbahaya. Bahkan bahaya metana dianggap beberapa ilmuwan lebih berbahaya daripada karbondioksida (CO2). Penelitian ini dianggap masuk akal karena laut merupakan penghasil metana paling besar di alam selain di lapisan es atau tanah. Bahkan 
pada tahun 1981, sebuah uji coba seolah membenarkan jika segitiga bermuda memiliki kandungan metana dalam jumlah besar. Yang bisa menjadi biang keladi mengapa banyak pesawat dan kapal laut hilang di sana.

Salah satu dugaan adalah bahwa tempat itu adalah lokasi kota Atlantis yang hilang. Edgar Cayce meramalkan bahwa pada tahun 1968 arkeolog akan menemukan pintu masuk ke kota Atlantis tenggelam di dekat Bimini di Segitiga Bermuda. Pada saat itu batu yang membentuk dinding ditemukan terbenam secara disengaja di sebuah pulau di Bahama dan banyak yang beranggapan ini adalah bukti dari kota Atlantis yang hilang. Menurut legenda, kota Atlantis mempunyai pembangkit energi dari kristal dimana sampai hari ini masih mengirimkan gelombang energi, karena lokasi kristal yang terkubur di bawah laut yang menyebabkan kapal dan pesawat akan terganggu pada peralatan navigasinya. Teori konspirasi hari ini juga berspekulasi tentang sebuah pangkalan militer di bawah air yang dikenal sebagai Underwater Area 51, salah satu alasan untuk misteri di Segitiga Bermuda.

Teori Tentang Misteri Segitiga Bermuda Kecelakaan aneh di Segitiga Bermuda telah dikaitkan dengan bukti masalah kompas dan navigasi, membuat bidang geomagnetik sebagai kasus nyata, dan teori masuk akal untuk penghilangan yang terjadi di Bermuda. Masalah dengan peralatan magnetik dari medan geomagnetik adalah 5 dari sepuluh alasan utama Segitiga Bermuda menjadi begitu membingungkan. Banyak teori bahwa ada anomali magnetik di daerah tersebut dan bahwa wilayah ini termasuk salah satu dari hanya dua tempat di bumi di mana kutub utara dan magnet utara membujur yang dapat menhasilkan bervariasi hasil pada peralatan navigasi. Dalam kaitannya dengan teori 'kabut elektronik' oleh Rob MacGregor dan Bruce Gernon, badai elektromagnetik yang kuat dari dalam bumi menembus ke permukaan dan datang ke atmosfir, lalu meninggalkan kabut di belakangnya.

Arus Teluk hampir seperti sebuah sungai dalam laut yang berasal dari Teluk Meksiko dan mengalir melalui Selat Florida ke Atlantik Utara. Ini mencakup 40 sampai 50 mil luas wilayah dan dapat membawa puing-puing hingga kecepatan permukaan 5,6 mil per jam untuk 2-4 simpul arus dan hal ini tergantung pada pola cuaca. Arus Teluk dapat dengan mudah memindahkan pesawat atau kapal tentunya, dan selanjutnya, Segitiga Bermuda termasuk sebagai beberapa palung laut terdalam di dunia, yang terdalam mendekati hampir 10.000 meter di bawah laut. Kapal tetap sangat mungkin ditelan oleh laut ke parit jika tidak oleh arus. Tanpa diduga gelombang tinggi juga telah dilaporkan hingga delapan puluh meter di luar Arus Teluk, menambah sulitnya mencari kapal dan pesawat hilang di laut

\section{Kesimpulan}

Fenomena Segitiga Bermuda adalah misteri yang belum terpecahkan hingga saat ini. Peristiwa banyaknya kehilangan tanpa jejak di Segitiga Bermuda adalah fakta yang telah menyebabkan munculnya banyak teori dan spekulasi. Rasa penasaran pun memicu dan memacu banyak pihak untuk mencari pencerahan. Berbagai opini dan teori bermunculan entah salah atau benar.

Menemukan lokasi pasti dari Segitiga Bermuda adalah pencarian membingungkan. Banyak yang berpikir Segitiga Bermuda, yang juga dikenal sebagai Segitiga Setan sebagai daerah "khayalan" atau "Imajiner". Bahkan, dewan resmi bidang geografi AS bahkan tidak mengakui keberadaan Segitiga Bermuda. Namun, dalam wilayah imajiner tersebut, berdasarkan fakta Segitiga Bermuda adalah tempat yang sangat nyata di mana selusin kapal, pesawat dan orang-orang telah menghilang tanpa penjelasan berarti.

Walau tidak akan ditemukan di setiap peta resmi dan bahkan kita tidak akan tahu kapan melewati wilayah tersebut, Segitiga Bermuda sesungguhnya adalah sebuah daerah di bagian barat Samudra Atlantik Utara, dan dibatasi oleh titik-titik di Bermuda, Florida dan Puerto Rico. Ini membentang di kurang dari seribu mil pada satu sisi atau mencakup sekitar 500.000 mil persegi.

\section{Daftar Pustaka}

Descartes, R. 1986. Meditations of First Philosophy, with selections from the Objections and Replies. Trans. John Cottingham, introd. by Bernard Williams. Cambridge, UK: Cambridge University Press.

Diski, J. 2008. Diary: On not liking South Africa. London Review of Books 30(13), 2003 July:41. 
Ekman, P., and W. Friesen. 1975. Unmasking the face: A guide to recognizing emotions from facial expressions. Englewood Cliffs, NJ: Prentice-Hall.

Fodor, J. 1983. The modularity of mind. Cambridge, MA: MIT Press, A Bradford book.

Firman Hary (2016). Perkembangan ilmu. Bahan ajar filsafat ilmu. Program doctoral UPI. Tidak diterbitkan

James Ladyman (2002). Understanding Phylosophy of science. London and New York http://id.wikipedia.org/wiki/segitiga_bermuda.

http://www.akujagoan.com/2009/12/segitiga-bermuda-atau-biasa.html.

http://duniabaca.com/kisah-misteri-segitiga-bermuda-lengkap.html.

http://rumahp1 nt4r.blogspot.co.id/2014/03/misteri-segitiga-bermuda-terungkap-oleh.html.

http://indozones.blogspot.co.id/2015/01/22.7-Fakta-Mengerikan-Tentang-Segitiga-

Bermuda.html.

http://rumahp1 nt4r.blogspot.co.id/2014/03/misteri-segitiga-bermuda-terungkap-oleh.html. 